\title{
Metaforyczne ożywianie miasta Praktyka na pograniczu nauki i sztuki
}

\section{Wstęp}

W polskim dyskursie naukowym i publicystycznym związanym z obszarem zarządzania miastem od ponad dwóch dekad pojawia się pojęcie rewitalizacji (jego łaciński źródłosłów, połączenie re i vita, oznacza przywrócenie do życia). Termin ten jest zbudowany na metaforze ukazującej działanie na rzecz miasta jako odpowiednik rekultywacji jałowego fragmentu ziemi lub opieki nad obumierającym organizmem, który dzięki terapii otrzymuje nową dawkę sił witalnych.

Pionierzy kognitywnej teorii metafor - George Lakoff i Mark Johnson (2010) - zauważyli, że są one tak powszechnym zjawiskiem, że często nie dostrzegamy ich roli. Konceptualizują one jednego rodzaju doświadczenie (abstrakcyjne) za pomocą innego (powszechnego, codziennego, łatwiejszego do zobrazowania). Zoltán Köveces (2006: 247) twierdzi, że metafora nie jest zjawiskiem wyłącznie językowym i pojęciowym, ale może wpływać na życie codzienne poprzez kształtowanie naszego myślenia, stając się tym samym praktyką kulturową. Podążając za wnioskami z badań nad znaczeniem metafor, w artykule zarysuję, jak od XVIII wieku, za sprawą postępu w naukach medycznych, biologicznych oraz w ekologii, zmieniało się postrzeganie metaforycznego życia miasta. Szczególną uwagę zwrócę na prowadzony w środowisku awangardowych architektów i artystów spór pomiędzy zwolennikami dwóch koncepcji urbanistycznych: miasta modernistycznego i miasta sytuacjonistycznego. Twierdzę, że powstałe w ich ramach praktyki różniła odmienna recepcja metaforycznego miejskiego życia, a odmienność ta ma swoje konsekwencje do dziś. 


\section{Puls miasta}

Słowo „rewitalizacja” w ostatnich dwudziestu latach bywało i jest używane bardzo różnorodnie: raz określa ono wymianę infrastruktury, inwestycje pobudzające gospodarkę, innym razem projekty z zakresu pomocy socjalnej, a nawet działania o charakterze tożsamościowym. Od 2015 roku rewitalizacja ma już swoją definicję w polskim prawie:

[...] proces wyprowadzania ze stanu kryzysowego obszarów zdegradowanych, prowadzony w sposób kompleksowy, poprzez zintegrowane działania na rzecz lokalnej społeczności, przestrzeni i gospodarki, skoncentrowane terytorialnie, prowadzone przez interesariuszy rewitalizacji na podstawie gminnego programu rewitalizacji (Ustawa z dnia 9 października 2015 r. o rewitalizacji).

Zarysowany w ustawie obraz miejskiego życia dotyczy bezpośrednio stanu ludzi i przedmiotów na danym obszarze, który ogarnięty jest kryzysem. Kiedy stan ten nie pasuje do normy danego miasta, metaforyczne życie przygasa lub toczy się w „zdegradowanej” formie i wymaga szczególnej, „zewnętrznej” interwencji. Takie rozumienie prowadzi nasze wyobrażenia na przykład w kierunku działań o charakterze rekultywacji obszaru skażonego, dotkniętego pożarem czy suszą, w którym życie samoistnie nie może się już odrodzić. Zmierzamy ku wyobrażeniu miasta jako zbioru różnorodnych ekosystemów, kolonii, ekotonów, nie zaś jako jednego organizmu.

Richard Sennett w swojej publikacji Ciało i kamień. Człowiek i miasto w cywilizacji Zachodu (1996) ukazuje, jak historycznie przestrzeń miasta nabiera ksztattu - przede wszystkim za sprawą tego, w jaki sposób ludzie odbierają własne ciało. Odwołuje się do przykładów z kręgu kultury europejskiej, zaczynając od starożytności - greckich polis oraz koncepcji rzymskiego architekta Witruwiusza i zmierzając do zmian wywołanych przez rewolucję naukową. Jego zdaniem miasto-organizm początków nowoczesności zmieniło się pod wpływem publikacji De motu cordis Wiliama Harveya, wydanej w 1628 roku. Podawała ona w wątpliwość poglądy ugruntowane między innymi na podstawie prac starożytnego lekarza Galena o produkcji życiodajnej krwi w sercu. Harvey stwierdzit, że serce jest mięśniem, który kurcząc się, wypycha krew do tętnic. Wysunął pogląd, że krew przepływa przez serce w dwóch osobnych, zamkniętych układach: krążenia płucnego i systemowego. Sennett (1996: 208-226) pokazuje, jak przebiega droga od odkrycia Harveya w dziedzinie medycyny do projektów urbanistycznych epoki oświecenia. 
Miasto - jak sugerowały odkrycia związane z cielesną mechaniką zdrowego organizmu - musi mieć wydolny „krwiobieg” i „oddychać”. System miejskiej komunikacji w nomenklaturze osiemnastowiecznych architektów począł funkcjonować jako system „tętnic” i „arterii”, który gdzieniegdzie niebezpiecznie „się tamował”. Zaczęto też myśleć o cyrkulacji płynów i nieczystości, przywiązywać wagę do warunków higienicznych, regularnie sprzątać przestrzenie publiczne i budować systemy kanalizacji. Sennett zauważa znaczące konsekwencje owego ciągłego udrażniania i jego polityczne znaczenie. Podejmuje wątek wysitków barona Georges’a-Eugène’a Haussmanna, który przebudowywał Paryż w połowie XIX wieku, po doświadczeniach rewolucji 1830 i 1848 roku, tworząc nowy układ szerokich ciągów komunikacyjnych i animując rozwój nowego typu zabudowy wokół nich: „Po pierwsze, komunikacja na ulicy straciła związek z zabudową, liczyła się tylko fasada; po drugie, miejska żyła, zamiast karmić śródmieście, była teraz drogą ucieczki" (Sennett, 1996: 265).

Paul Virilio (2008: 43) twierdzi, że to, co w rewolucyjnym 1789 roku postrzegano jako zyskanie wolności poruszania się, tylko na krótko przyczyniło się do emancypacji mas - następnie powoli wprzęgało je w przymus mobilności. Architektura nowoczesnego dziewiętnastowiecznego miasta i jej stan odpowiadały stanowi przepływu ulicy. Okno w budynku kierowało spojrzenie na ruch, miejsca architektoniczne w ten sposób stały się miejscami kumulacji, ograniczenia przyspieszenia i możliwości wnikania (Virilio, 2008: 15).

\section{Metabolizm w terenie zurbanizowanym}

O ile życie miasta jako metaforyczna cyrkulacja płynów i powietrza ukształtowało myślenie urbanistów, architektów i decydentów miejskich w XVIII wieku, to już w kolejnym stuleciu coraz częściej pojawiała się nowa kategoria, zaczerpnięta z tej samej dziedziny źródłowej: metabolizm. Miejski ruch zaczęto postrzegać jako proces przypominający szlak metaboliczny, co zauważa Erik Swyngedouw (2006), analizując wpływ tej koncepcji na rozwój miast. W XIX wieku metabolizm rozumiany był głównie jako wymiana materii wewnątrz ciała, natomiast w XX wieku znaczenia nabrały kwestie wytwarzania energii w złożonych reakcjach biochemicznych. Zarówno Swyngedouw, jak i Sennett (który nie poświęca w Ciele i kamieniu... wiele uwagi metabolizmowi) piszą o tym, jak w procesie przejścia wiedzy z zakresu funkcjonowania organizmu do urbanistyki pośredniczyły teorie ekonomiczne. Metafory organicznego krążenia, ilustrującej zachowanie się pracowni- 
ków i wymianę towarów, używał Adam Smith (co opisuje Sennett), natomiast do metabolizmu odwoływat się Karol Marks (o czym wspomina Swyngedouw).

Wydaje się, że oddziaływanie metafory metabolicznej jest wciąż bardzo duże. Brytyjski fizyk Geoffrey West, związany z badającym systemy złożone instytutem Santa Fe, w pracy Scale: The Universal Laws of Life and Death in Organisms, Cities and Companies przedstawit wyniki swoich dociekań na temat tego, jak zbadać „miejski metabolizm”, stosując odkrycia dokonane wspólnie z Jimem Brownem i Brianem Enquistem w kwestii formuły matematycznej wyrażającej korelację pomiędzy rozmiarami organizmu a przeciętnym okresem jego życia. Publikacja ta jest próbą połączenia metod stosowanych w biologii i socjologii, wzbogaconych o obszerne własne stanowisko na temat rozwoju metafory metabolicznej w zastosowaniu do badania miasta (West, 2017: 247-268). West podkreśla różnorodność i historyczność miast na świecie, ale przyjmuje, że rządzą nimi także uniwersalne struktury, które pojawiają się w każdej żywej, rozrastającej się metropolii i w każdym kurczącym się mieście. Westa najbardziej fascynuje to, jak ośrodki miejskie (w przeciwieństwie do firm, których „żywotność” jest ograniczona) potrafią stawać się coraz większe i trwać. West na podstawie swoich badań dochodzi do wniosku, że podwojenie liczby mieszkańców miasta (obojętnie, jaka jest jego wielkość) powoduje „efekt 15\%” - o tyle mieszkańcy (statystycznie) stają się bogatsi i bardziej innowacyjni. West (2017: 253-265) odnosi się do intuicji i poglądów dziennikarki, krytyczki architektury i filozofki miast Jane Jacobs, podkreślającej zalety zagęszczenia ludzkich interakcji w miejskim otoczeniu. Jednocześnie zaważa, że w rosnących miastach również o 15\% wzrastają różne wartości neutralne (np. szybkość, z jaką ludzie chodzą) i negatywne czynniki, takie jak przestępczość czy ryzyko uczestnictwa w wypadku samochodowym. Opisuje metaboliczną „premię", jaką otrzymują większe miejskie organizmy, dzięki czemu przyciągają kolejnych mieszkańców i stymulują własny rozrost (West, 2017: 325-337). Perspektywa Westa to próba wyjaśnienia, dlaczego miasta rosną. Nie odpowiada ona jednak na pytania, jak sprawić, żeby konkretne ośrodki rosły (przecież nie wystarczy wsadzić ludzi do pociągów i przywieźć do miasta) ani czy będą one rosły w nieskończoność. W badaniach nad miastem pojawiają się też koncepcje mówiące, że megalopolis mają charakter historyczny i ich epoka dobiegnie końca (Dobiesz, 2013: 85-88). 


\section{Modernistyczna wydolność}

Miejskie życie stało się metaforą, która wpłynęła na dwie ważne architektoniczno-artystyczne koncepcje rozwoju miast: miasta modernistycznego i miasta sytuacjonistycznego. Modernizm kojarzy się przede wszystkim z pozornie nieorganiczną metaforą miasta-maszyny, której propagatorem stał się szwajcarski architekt Charles-Édouard Jeanneret-Gris - Le Corbusier. Wzbudził on zainteresowanie, kiedy to z myślą o odbudowie Flandrii po zniszczeniach I wojny światowej zaproponowat schemat Domino - konstrukcję budynku z betonowych płyt wspartych na żelbetowych słupach. Po wojnie był współtwórcą pisma „L’Esprit Noveau” („Nowy Duch”), w którym prezentował swoje radykalne poglądy na sztukę. To właśnie retoryczne umiejętności i chwytliwe porównania uczyniły go jednym z najbardziej znanych protagonistów modernizmu w architekturze. Przełomem w jego karierze był rok 1922, kiedy to na paryskim Salonie Jesiennym (Salon d'Automne) przedstawit makietę miasta dla trzech milionów mieszkańców, zatytułowaną La Ville Contemporaine (Miasto wspótczesne). Miało się ono składać z sześciokondygnacyjnych wieżowców (dla burżuazji) oraz mniejszych „willi” (dla robotników), ustawionych równolegle względem siebie na oczyszczonych z innej zabudowy parcelach. Zdaniem twórcy architektura ta miała przede wszystkim sprzyjać wydajnemu gospodarowaniu ludzką energią i przeciwstawiać się „,zamachowi na życie”, jakiego dokonuje rozregulowany mechanizm rozrośniętego miasta współczesności:

Miasto to biologia. O człowieku słusznie mówi się, że jest „rurą trawienną z wejściem i wyjściem". U wejścia i u wyjścia z rury nie ma kościoła ani pałacu. Wolne przejście! To podstawowy warunek zdrowego miasta: musi się dać je swobodnie przemierzyć, nawodnić, nakarmić z każdej strony! (Le Corbusier, 2013: 74).

Mimo że Le Corbusier był zafascynowany produkcją przemysłową (współczesnymi samolotami, samochodami), podziwiał jej skuteczność oraz wydajność i chciał odnaleźć podobną w architekturze, jego poglądy na miasto były w dużej mierze rozwinięciem medycznych metafor cyrkulacyjno-metabolicznych. Interesowało go, jak współczesnemu, ciężko pracującemu człowiekowi zorganizować wygodne, przyjemne i higieniczne życie. Swoje estetyczne i funkcjonalne wybory uzasadniał, podobnie jak Witruwiusz, odniesieniem do swojej interpretacji ludzkich proporcji, które wyznaczał obraz mężczyzny mierzącego $183 \mathrm{~cm}$, z podniesioną ręką. Dodatkowo dla Le Corbusiera niezwykle ważne były: idea nieskrępowanego ruchu jednostki, szybkość transportu samochodowego i dobry 
przepływ powietrza. Po wizycie w Stanach Zjednoczonych zaproponowat dla Nowego Świata taki oto typ budynku:

Kartezjański drapacz chmur to cud urbanistyki i cywilizacji maszyn. W niebywałym stopniu koncentruje ludność: nawet do 3-4 tysięcy osób na hektar. Dokonuje tego, zajmując jedynie od pięciu do siedmiu procent powierzchni. Zatem od 93 do 95 procent zostaje zwrócone, jest do wykorzystania dla ruchu pieszego i kołowego! (Le Corbusier, 2013: 78).

W ten sposób nowe miasta miały być wolne od takich „chorób”, jak nadmierne zagęszczenie, korki na ulicach, brak słońca, czystego powietrza i zieleni (lub ich zła dystrybucja). Jak zauważył David Harvey (1996: 29), kłopot z modernistyczną koncepcją leczenia chorego „miejskiego organizmu” polegat nie na zarzucanej jej totalitarnej kontroli jednostki w przestrzeni, ale na wierze, że można sterować społeczeństwem za pomocą powtarzalnych, ahistorycznych układów form przestrzennych. Sztywne reguły sprawiały, że ciało podlegało nieustannej presji krążenia w zaaranżowanym obiegu, w trajektoriach wyznaczanych przez pracę, odpoczynek, utrzymanie zdrowia i kondycji fizycznej.

\section{Sytuacjonistyczna różnorodność}

Druga koncepcja stała w radykalnej opozycji do modernizmu, nazywając miasta nowoczesności „miastami pokuty”, „koszarami” (Międzynarodówka Letrystyczna, 2016: 49-53) czy „slumsami” (Condor, 2016: 45). Jej genealogia jest dość skomplikowana. Zalążkiem sytuacjonizmu był letryzm, filozofia Isidore’a Isou, który zaraził nią grupę kontestującej młodzieży, w tym Guy Deborda. To on z czasem stał się czołowym strategiem dalszej fazy ruchu, powołując w 1952 roku Międzynarodówkę Letrystyczną, która w 1957 roku przeistoczyła się w Międzynarodówkę Sytuacjonistyczną. Napisał też najważniejsze opracowanie teoretyczne ruchu, czyli Społeczeństwo spektaklu. Pisał w nim:

[...] życie społeczeństw, w których panują nowoczesne warunki produkcji, przypomina olbrzymie zbiorowisko spektakli. Wszystko, co dawniej przeżywano bezpośrednio, oddaliło się, przybierając postać przedstawienia (Debord, 2009: 33).

Debord był czołowym teoretykiem sytuacjonistycznych „badań” nad miastem. Ukut on pojęcie psychogeografii, która według niego mogłaby sformułować pra- 
wa dotyczące bezpośredniego oddziaływania środowiska geograficznego, świadomie zagospodarowanego lub nie, na afektywne zachowania jednostek (Debord, 2016b: 77). Ostatecznie sytuacjonistyczne praktyki miejskie (dryf) i teoretyczne koncepcje (psychogeografia) nigdy nie zostały ujęte w ramy jednoznacznie sprecyzowanej zasady czy metodologii. Być może dlatego, że - jak twierdzi Mateusz Kwaterko (2016: 20) - urbanistyka miała być dla Deborda przyczółkiem, z którego wyprowadzić chciał kolejne ataki na społeczeństwo. Warto też zaznaczyć, że sytuacjoniści nie prowadzili regularnych badań ani nie doprowadzili do realizacji swoich wizji miast. Zachowały się pisma, grafiki i wspomnienia dające pewien wgląd między innymi w to, jak czerpali oni z metafory życia miasta. Niezadowolenie z modernistycznej jego recepcji jako metabolicznego ciała skłaniało ich bardziej w kierunku poetyki różnorodności, ujmującej miejskie życie jako zbiór habitatów tworzonych przez liczne organizmy, które niejednorodnie ich doświadczają i z nich korzystają.

Debord w Teorii dryfu próbuje skłonić czytelnika do zastanowienia się, czym jest „realny Paryż” dla konkretnej jednostki. Widzi tyle realnych Paryżów, ilu jest mieszkańców, gdyż każdy z nich rozrysowuje swoją indywidualną siatkę, po której na co dzień się porusza (Debord, 2016c). W swoich rozważaniach odwołuje się do prac antropologicznych i socjologicznych, między innymi do badań Paula-Henry'ego Chombard de Lauwe (Paris et l'aglomeration parisienne, 1952). Wspomina także „teorie Burgessa”, opisujące społeczne zróżnicowanie Chicago w graficznym ujęciu kręgów koncentrycznych (Hannerz, 2006: 124). Debord prawdopodobnie zetknął się z koncepcjami szkoły chicagowskiej i pisząc o „teoriach Burgessa”, miał na myśli prace Roberta Parka (reportera śledczego rozczarowanego dziennikarstwem) oraz jego młodszych współpracowników: Rodericka McKenzie’ego i wspomnianego już Ernesta Burgessa, którzy dokładniej opracowywali pojęcia zarysowane przez Parka i szukali ich praktycznych zastosowań. Park zdobył rozgłos dzięki serii artykułów podejmujących zagadnienie „ekologii człowieka”. Rozważał w nich problem miejskiej walki o byt - Ulf Hannerz (2006: 39) zauważa w tym podejściu inspiracje społecznym darwinizmem, zakładającym, że w ludzkich zbiorowościach istnieje „poziom podspołeczny”, „biotyczny”. Park widział analogię między tworzeniem się społecznych struktur miasta i ekologią roślin. W serii swoich artykułów dotyczących ludzi mieszkających w Chicago używał więc takich pojęć jak „dominacja” czy „następstwo”, ale najważniejsza była dlań „konkurencja” (Hannerz, 2006: 40). Najsilniejsi mieszkańcy zajmowali najlepsze miejsca, a inni dopasowywali się do ich wyborów. Dodatkowo Park używał pojęcia symbiozy, zgodnie z którą różni mieszkańcy czerpią korzyści z koegzystencji w obrębie jednego środowiska - był to czynnik modyfikujący schematy. Jedną z ważnych, ścisłych danych do wyznaczania stref ekologicznych (dzielnic niezaprojektowanych, które 
„wyrosły” w wyniku zachodzących w mieście procesów) była zmiana wartości gruntów. Właśnie na tej podstawie diagram kół koncentrycznych dzielił miasto na strefy. Pierwszy krąg stanowiła dzielnica biznesowa, w której ziemia miała najwyższą wartość. Drugą strefę, przejściową, kolonizował biznes i lekki przemysł, czyniąc ją nieatrakcyjną dla zamożniejszych mieszkańców. Kolejne dwie strefy były głównie mieszkalne, a ostatni, piąty krąg był strefą „dojazdów do miasta” osób związanych z nim, ale w nim niemieszkających.

Debord nazywał antropologów i socjologów ze szkoły chicagowskiej oraz ich europejskich kolegów, w związku z biologiczną terminologią, „ekologami”. Jednocześnie wyrażał wątpliwości wobec metod ilościowych i możliwości pozyskiwania „ścisłych danych” w potencjalnej psychogeografii, twierdząc, że badani mają ograniczoną świadomość swoich relacji z miastem. „Ekologia, gdy usituje badać nastroje-otoczenie za pomocą zwyczajnych ankiet, grzęźnie w ruchomych piaskach niestosownego języka" (Debord, 2016a: 226). Debord przytacza przykład telewizyjnej debaty z 1959 roku na temat dzielnicy Mouffertard. Mieszkańcy oraz „ekolog” zgodzili się, że jest to:

[...] cuchnący i niehigieniczny obszar wypełniony przeraźliwymi ruderami, jednocześnie zaś orzekli, że jest to wspaniałe miejsce do życia. [...] W tej dziedzinie muszą się dopiero pojawić praktycy-teoretycy nowego rodzaju, którzy będą potrafić mówić o wpływie urbanistyki, a także modyfikować ów wpływ (Debord, 2016a: 226).

Najbardziej brawurowym, a zarazem syntetycznym tekstem o sytuacjonistycznej koncepcji miasta jest napisany w 1953 roku Zarys nowej urbanistyki Iwana Szczegłowa (Gillesa Ivaina). Współczesne mu miasto stawia on w opozycji do tego tworzonego przez dawne wspólnoty, posiadające „absolutną prawdę i mityczne wzorce”. Współczesną „cywilizację” określa jako „ruchomą”. W poetycki sposób opisuje użycie najważniejszych technik sytuacjonistycznych wobec komfortu i banalizacji, które porównuje do umysłowej choroby opanowującej współczesne miasto. $W$ nowoczesnym mieście młodzież otrzymała wybór między „miłością a automatycznym zsypem na śmieci” i wybrała zsyp (Gilles, 2016: 36). W jego tekście urbanistyka, a raczej miasto samo w sobie, wyrywa człowieka z hipnozy komfortu i banalnie wykonywanych czynności, staje się środkiem stymulującym możliwości działania i poznawania (Gilles, 2016: 35-38). Tekst ten proponuje także konstruktywną wizję nowego miasta, w którym poszczególne dzielnice odpowiadają uczuciom - są na przykład dzielnice: dziwaczna, szczęśliwa, tragiczna, użyteczna, ponura. Zasadniczą aktywnością mieszkańców ma być „bezustanne dryfowanie", rozumiane jako ciągła zmiana krajobrazu, która będzie powodować 
całkowite wyobcowanie (depaysment) (Gilles, 2016: 39). W przeciwieństwie do miasta metabolicznego, w którym ruch jest zaprogramowany, a podmiot wprzęgnięty w jego rytm, tu podmiot ma sam stanowić reguły - cyrkulować, podążając za własną intuicją, wyobraźnią i oczekiwaniami, czerpać z wykreowanego dla niego środowiska, ale nie być przez nie determinowanym. Mamy tu do czynienia z ciągłą migracją i penetracją coraz to nowszych miejsc, nowych, mających silną tożsamość habitatów, a nie z pełnieniem określonej funkcji w systemie. Wędrówka ta staje się środkiem do samodoskonalenia - rozumianego także jako umiejętność adaptacji i wrażliwość na bodźce. Szczegłow podsumowuje ten pomysł pełnym patosu zdaniem: „Takie miasto stałoby się po kilku latach intelektualną stolicą świata i za takie zostałoby uznane" (Gilles, 2016: 40).

\section{Heurystyka koncepcji artystycznych a rewitalizacja}

Analizując koncepcje miasta modernistycznego i sytuacjonistycznego, które są w swojej istocie awangardowymi, artystycznymi wizjami, można dostrzec, jak sztuka posługuje się metaforami, wypracowując własne modele heurystyczne - podobnie jak nauka. Obie dziedziny z tego i z innych względów pozostają w (czasem nieuświadomionej) relacji i wpływają na siebie.

Obie wyżej opisane koncepcje analizowały miejskie życie jako ruch. Koncepcja modernistyczna miała na celu ten ruch jak najbardziej ułatwić poprzez możliwie prostą i sprawną organizację miejskiego życia, aby człowiek miał więcej czasu na inne aktywności. Sytuacjoniści widzieli w tej koncepcji zagrożenie banalizacją, automatyzacją i szczególnym konformizmem, który zabijał wrażliwość, przenosząc doświadczenie ogłupiającego komfortu, uzyskiwanego w pozycji zarówno uczestnika, jak i widza miejskiego spektaklu. Sennet opisuje zjawisko życia miasta jako krążenia w następujący sposób:

Pojedyncze ciała, pokonując przestrzeń miejską, stopniowo się odrywały od tej przestrzeni i od zamieszkujących ją ludzi. Podczas gdy przestrzeń traciła wartość za sprawą ruchu, człowiek tracił poczucie, że dzieli własny los z innymi (Sennet, 1996: 259).

Ruch (dryf) w koncepcjach sytuacjonistycznych nie miał na celu wygodnego odcięcia się od doświadczenia, ale miał być swoistą terapią, pozwalającą na wzmocnienie i stymulowanie umiejętności poznawczych. Ruch modernistycznego miasta to krążenie, w którym pojedyncza „krwinka” jest kierowana arteriami w kolejne ważne dla organizmu miejsca. Dryf to zaprzeczenie tak wyznaczonej 
hierarchii miejsc i zachęcenie do podjęcia ryzyka bezcelowości. Jest to koncepcja inspirująca, ale również wymagająca i w pewnym sensie elitarna.

Życie miasta w obu koncepcjach to przede wszystkim życie jednostki, która z wielu praktycznych przyczyn wnika w miasto, a jednocześnie się od niego dystansuje. W modernizmie tworzy wspólnotę, ale nie musi się angażować w jej kształtowanie, gdyż powstaje ona jakby samoistnie - za sprawą ekspertów czuwających nad tym procesem. W sytuacjonizmie wspólnota powstaje w ruchu, w czasie przeżywania i zawiązywania relacji, a więc nie jest trwała.

Warszawski artysta Paweł Althamer zyskał popularność dzięki obrazowi bloku mieszkalnego, którego okna „wyświetlały” liczbę 2000 z okazji nadejścia tego właśnie roku. Obraz ten był efektem performatywno-partycypacyjnej akcji z 27 lutego 2000 roku, która miała miejsce przy ulicy Krasnobrodzkiej 13 na warszawskim Bródnie - w budynku, w którym mieszkał artysta. Efekt wyświetlenia „2000" był wynikiem nawiązania przez artystę relacji z niemal dwustoma sąsiadami i przekonania ich do wspólnego działania w atmosferze karnawału wejścia w nowe tysiąclecie. Artyście udało się zaktywizować współmieszkańców bloku, którzy nawet sami wykazali inicjatywę, organizując między innymi pokaz sztucznych ogni. Althamer zainicjował przedsięwzięcie, które było rodzajem subwersywnego wykorzystania przestrzeni na co dzień użytkowanej w celach praktycznych. Wydarzenie było możliwe do zrealizowana ze względu na szczególny moment. Artysta nie próbował kontynuować tej formuły. Chcąc dalej aktywizować mieszkańców do twórczego działania, zdecydował się między innymi wypracować z nimi w 2009 roku unikatowe miejsce, w którym mogą zachodzić różnorodne zdarzenia - Park Rzeźby na Bródnie. Park ten nie jest statycznym dziełem, które należy jedynie kontemplować, lecz przestrzenią spotkań i eksperymentów zarówno dla profesjonalnych twórców, jak i dla samych mieszkańców, w której wiele z wytworzonych instalacji jest używanych i reinterpretowanych. Działania Althamera to tylko przykład wskazywany przez teoretyków w ramach szerszego globalnego ruchu twórców zorientowanych na wytwarzanie momentów wspólnotowości, uwrażliwiających, stymulujących poznawczo za sprawą przestrzeni. Heurystyka wielu podobnych artystycznych działań o charakterze angażującym przekonuje, że wspólnota jest wytwarzana (procesualna), a powtórzone w innym miejscu i w innym czasie podobne działania nie gwarantują zbliżonego efektu. Rewitalizacja w swojej prawnie określonej definicji (którą traktuję jako zwycięstwo pewnego uzusu językowego wynikającego z konkretnych poglądów na jej temat) jest ożywianiem poprzez odbudowywanie wspólnotowości na danym obszarze. Wnioski z obserwacji podobnych do realizowanych na warszawskim Bródnie praktyk artystycznych przekonują, że potrzebny jest do tego ruch nie o charakterze metabolicznym, ale raczej przypominający sy- 
tuacjonistyczny dryf - może nieco bardziej angażujący we wspólnotowe doświadczenie, niż to formułowali paryscy awangardziści, ale równie elastyczny i otwarty na eksperyment. Takie działania trudno poddać szczegółowemu planowaniu i parametryzowaniu. Parametryzacja praktyk rewitalizacyjnych najczęściej bliższa jest metabolicznej koncepcji życia miasta, z której łatwiej można wyciągnąć wnioski, obserwując dynamikę zmian konkretnych współczynników (tj. wskaźników bezrobocia, kondycji gospodarczej gospodarstw domowych czy wartości gruntów i infrastruktury). Z perspektywy specyfiki wspólnotowości miejskiej „przebadanej” przez artystów w zestawieniu z normatywnym performansem życia miasta, rozumianego jako układ metaboliczny, każde realne działanie rewitalizacyjne jest niepowtarzalnym eksperymentem, który udaje się częściej dzięki obserwacji i improwizacji niż dzięki sztywnym procedurom.

\section{Bibliografia}

Condor A.F. (2016), Budowa slumsów, [w:] M. Kwaterko, P. Krzaczkowski (red.), Przewodnik dla dryfujących. Antologia sytuacjonistycznych tekstów o mieście, Warszawa: Fundacja Bęc Zmiana, s. 45.

Debord G. (2009), Społeczeństwo spektaklu, [w:] G. Debord, Społeczeństwo spektaklu oraz Rozważania o społeczeństwie spektaklu, przeł. M. Kwaterko, Warszawa: Państwowy Instytut Wydawniczy, s. 31-144.

Debord G.-E. (2016a), Ekologia, psychogeografia i przekształcanie miejskiego środowiska, [w:] M. Kwaterko, P. Krzaczkowski (red.), Przewodnik dla dryfujących. Antologia sytuacjonistycznych tekstów o mieście, Warszawa: Fundacja Bęc Zmiana, s. 221-228.

Debord G.-E. (2016b), Wstęp do krytyki geografii miejskiej, [w:] M. Kwaterko, P. Krzaczkowski (red.), Przewodnik dla dryfujących. Antologia sytuacjonistycznych tekstów o mieście, Warszawa: Fundacja Bęc Zmiana, s. 75-81.

Debord G.-E. (2016c), Teoria dryfu, [w:] M. Kwaterko, P. Krzaczkowski (red.), Przewodnik dla dryfujących. Antologia sytuacjonistycznych tekstów o mieście, Warszawa: Fundacja Bęc Zmiana, s. 122-129.

Dobiesz S. (2013), Kurczenie się miast jako droga do naszego przeznaczenia, ,'Środowisko Mieszkaniowe”, nr 11, s. 85-88.

Gilles I. (2016), Zarys nowej urbanistyki, [w:] M. Kwaterko, P. Krzaczkowski (red.), Przewodnik dla dryfujących. Antologia sytuacjonistycznych tekstów o mieście, Warszawa: Fundacja Bęc Zmiana, s. 33-40.

Hannerz U. (2006), Odkrywanie miasta. Antropologia obszarów miejskich, przeł. E. Klekot, Kraków: Wydawnictwo Uniwersytetu Jagiellońskiego.

Harvey D. (1996), Kwestia urbanizacji, „,Kultura i Społeczeństwo", nr 4, s. 15-42.

Köveces Z. (2006), Język, umysł, kultura, przeł. A. Kowalcze-Pawlik, Kraków: Wydawnictwo Universitas.

Kwaterko M. (2016), Bojownicy Szwambranii, [w:] M. Kwaterko, P. Krzaczkowski (red.), Przewodnik dla dryfujących. Antologia sytuacjonistycznych tekstów o mieście, Warszawa: Fundacja Bęc Zmiana, s. 13-28.

Lakoff G., Johnson M. (2010), Metafory w naszym życiu, przeł. T. Krzeszowski, Warszawa: Wydawnictwo Aletheia.

Le Corbusier (2013), Kiedy katedry były białe. Podróż do kraju ludzi nieśmiałych, przeł. T. Swoboda, Warszawa: Centrum Architektury.

Międzynarodówka Letrystyczna (2016), Drapacze chmur od korzeni, [w:] M. Kwaterko, P. Krzaczkowski (red.), Przewodnik dla dryfujących. Antologia sytuacjonistycznych tekstów o mieście, Warszawa: Fundacja Bęc Zmiana, s. 49-51.

Sennett R. (1996), Ciało i kamień. Człowiek i miasto w cywilizacji Zachodu, przeł. M. Konikowska, Gdańsk: Wydawnictwo Marabut.

Swyngedouw E. (2006), Metabolic urbanization: the making of cyborg cities, [w:] N. Heynen, M. Kaika, E. Swyngedouw (red.), In the Nature of Cities. Urban Political Ecology and the Politics of Urban Metabolism, London: Routledge, s. 21-40.

Ustawa z dnia 9 października 2015 r. o rewitalizacji (Dz.U. z 2015 r., poz. 1777).

Virilio P. (2008), Prędkość i polityka, przeł. S. Królak, Warszawa: Wydawnictwo Sic!

West G. (2017), Scale: The Universal Laws of Life, Growth, and Death in Organisms, Cities, and Companies, London: Weidenfeld \& Nicolson. 